\section{Planting Arrangement and Density of Transplants Influence Sweet Spanish Onion Yields and Bulb Size}

\author{
Peter J. Stoffella \\ Indian River Research and Education Center, Institute of Food and Agricultural \\ Sciences, University of Florida, 2199 South Rock Road, Fort Pierce, \\ FL 34945-3138
}

Additional index words. Allium cepa, plant population, plant spacing

\begin{abstract}
Sweet Spanish onion (Allium cepa L. cv. Granex 33) was transplanted in two, three, or four rows per bed at $7.6,15.2$, or $22.9 \mathrm{~cm}$ in-row spacings resulting in plant populations ranging from 41,000 to 246,000 plants/ha during Winter 1991. Interactions between number of rows per bed and in-row spacings were nonsignificant for onion yield and bulb size traits. As number of rows per bed increased or in-row spacings decreased, marketable onion yield linearly increased and mean bulb size $(\mathrm{g} / \mathrm{bulb})$ decreased. Percentage of small, medium, and large bulbs was unaffected by number of rows per bed, but percentage of small and medium-sized bulbs increased and percentage of large bulbs decreased as in-row spacing decreased. Onion yields linearly increased, but at the expense of smaller-sized bulbs, whether plant populations were increased by more rows per bed or narrower in-row spacings.
\end{abstract}

Selection of optimum plant populations is one critical decision that onion growers must address before planting. In Florida, transplanting is recommended for onion plant populations $<197,000$ plants/ha and direct-seeding for plant populations of 247,000 plants/ha or greater(Hayslip et al., 1987). Generally, higher onion yields occur with increasing plant populations (plants/ha) (Bleasdale, 1966; Brewster and Salter, 1980; Kelbertet al., 1962; McGeary, 1985). The objective of this investigation was to determine the effects of increasing plant populations and varying planting arrangement on yield and bulb size of sweet Spanish onions.

\section{Materials and Methods}

The experiment was conducted at the Indian River Research and Education Center, Ft. Pierce, Fla. Soil was characterized as Oldsmar fine sand (sandy, siliceous, hyperthermic, Alfic Arenic Haplaquods). Raised beds, $15 \mathrm{~cm}$ high, $1.1 \mathrm{~m}$ wide, and $2.1 \mathrm{~m}$ apart, were constructed fertilizer at $192 \mathrm{~N}-70 \mathrm{P}-138 \mathrm{~K}\left(\mathrm{~kg} \cdot \mathrm{ha}^{-1}\right)$ was broadcast and soil incorporated into the beds. Due to heavy rainfalls during January and February totaling $25.4 \mathrm{~cm}$, additional fertilizer (83N-13P-36K; kg.ha ${ }^{-1}$ ) was broadcast onto the beds on 7 Feb. 1991. Continuous subsurface irrigation was used throughout the growing season. Standard pest control practices were used as needed to control insects, dis-

Received for publication 8 Mar. 1996. Accepted for publication 12 July 1996. Univ. of Florida Agriculture Experiment Station Journal series R-0487. The cost of publishing this paper was defrayed in part by the payment of page charges. Under postal regulations, this paper therefore must be hereby marked advertisement solely to indicate this fact. ${ }^{1}$ Professor. were subjected to an analysis of variance an main effect means separated into orthogonal

${ }^{2}$ Ratio of between-row spacing and in-row spacing. contrasts by the SAS software program (SAS Inst., 1989).

\section{Results and Discussion}

Rows per bed $\times$ in-row spacing interactions were nonsignificant for each measured trait; therefore, main effects of rows per bed and in-row spacing only are presented (Table 2). Marketable onion yields increased linearly and mean bulb size (g/bulb) decreased linearly as number of rows per bed increased from two to four or in-row spacing decreased from 22.9 to $7.6 \mathrm{~cm}$ (Table 2). Percent cull bulbs were $<9 \%$ and were not significantly affected by number of rows per bed or in-row spacing treatments.

The majority of marketable bulbs were large $(>7.6 \mathrm{~cm})$ regardless of plant population. Distribution of onion bulb sizes was not affected by the number of rows per bed (Table 2). However, there was a quadratic or linear increase in percentage of small or mediumsized bulbs, respectively, as in-row spacing decreased. As in-row spacing decreased, there was a quadratic decrease in percentage of large bulbs. Onion yields or bulb size was influenced by number of rows per bed and inrow spacing, with no differential yield response between row number per bed and inrow spacing (Table 2). Overall, onion yields can potentially increase with higher plant populations than those tested, but at a sacrifice of producing smaller bulbs.

Onion planting arrangements with rectangularity of 8:1 resulted in 15\% to $20 \%$ (Brewster and Salter, 1980) and 10\% (Frappell, 1973) onion yield reductions as compared to $1: 1$ (square) rectangularity spacing patterns. Our plant population ranged from rectangularity of $6: 1(45.7 \mathrm{~cm}$ between-row and $7.6 \mathrm{~cm}$ in-row spacing) to $1: 1(22.9 \mathrm{~cm}$ between-row and $22.9 \mathrm{~cm}$ in-row spacing) (Table 1). Since our plant populations were confounded with plant arrangement in rectangularity, inferences between onion yields and rectangularity would be difficult to ascertain.

Our data suggests that onion yields increased with higher plant populations but at the expense of smaller bulbs. These results are similar to those reported by McGeary (1985). Further studies are required to assess the economical constraints of growing onions at higher plant populations with related higher production costs and potentially higher yields but smaller sized bulbs than those grown at lower plant populations.

Table 1. Onion plant populations at various planting arrangements.

\begin{tabular}{|c|c|c|c|c|}
\hline \multirow{2}{*}{$\begin{array}{l}\text { Rows/bed } \\
\text { (no.) }\end{array}$} & \multicolumn{2}{|c|}{ Spacing $(\mathrm{cm})$} & \multirow[b]{2}{*}{ Rectangularity ${ }^{z}$} & \multirow{2}{*}{$\begin{array}{l}\text { Plant population } \\
\text { (plants/ha) }\end{array}$} \\
\hline & Between-row & In-row & & \\
\hline \multirow[t]{3}{*}{2} & 45.7 & 7.6 & $6: 1$ & 123,016 \\
\hline & 45.7 & 15.2 & $3: 1$ & 61,508 \\
\hline & 45.7 & 22.9 & $2: 1$ & 41,008 \\
\hline \multirow[t]{3}{*}{3} & 22.9 & 7.6 & $3: 1$ & 184,524 \\
\hline & 22.9 & 15.2 & $1.5: 1$ & 92,262 \\
\hline & 22.9 & 22.9 & $1: 1$ & 61,508 \\
\hline \multirow[t]{3}{*}{4} & 22.9 & 7.6 & $3: 1$ & 246,032 \\
\hline & 22.9 & 15.2 & $1.5: 1$ & 123,016 \\
\hline & 22.9 & 22.9 & $1: 1$ & 82,010 \\
\hline
\end{tabular}




\section{Crop Production}

Table 2. Mean onion yields and marketable onion bulb size distribution as influenced by plant population and planting arrangement.

\begin{tabular}{|c|c|c|c|c|c|c|}
\hline \multirow[b]{2}{*}{ Treatment } & \multicolumn{2}{|c|}{ Marketable yield } & \multirow[b]{2}{*}{ Culls $(\%)$} & \multicolumn{3}{|c|}{ Bulb size categories $(\%)^{\mathrm{z}}$} \\
\hline & ${\mathrm{Mg} \cdot \mathrm{ha}^{-1}}$ & g/bulb & & Small & Medium & Large \\
\hline \multicolumn{7}{|c|}{ Rows/bed (RB) } \\
\hline 2 & 18.2 & 287 & 4.9 & 7.5 & 26.1 & 66.4 \\
\hline 3 & 24.9 & 269 & 6.7 & 5.6 & 24.4 & 70.0 \\
\hline 4 & 27.7 & 227 & 7.8 & 10.0 & 32.6 & 57.4 \\
\hline Significance $^{y}$ & $\mathrm{~L}^{* *}$ & $\mathrm{~L}^{*}$ & NS & NS & NS & NS \\
\hline \multicolumn{7}{|c|}{ In-row spacing $(\mathrm{IRS})(\mathrm{cm})$} \\
\hline 7.6 & 29.2 & 176 & 3.0 & 14.8 & 42.1 & 43.1 \\
\hline 15.2 & 22.6 & 273 & 8.1 & 4.6 & 22.6 & 72.8 \\
\hline 22.9 & 18.5 & 333 & 8.3 & 3.7 & 18.4 & 77.9 \\
\hline Significance $^{\mathrm{y}}$ & $\mathrm{L}^{* *}$ & $\mathrm{~L}^{* *}$ & NS & $\mathrm{Q}^{*}$ & $\mathrm{~L}^{* *}$ & $\mathrm{Q}^{*}$ \\
\hline $\mathrm{RB} \times \mathrm{IRS}$ & NS & NS & NS & NS & NS & NS \\
\hline
\end{tabular}

${ }^{\mathrm{z}}$ Categories based on total marketable bulb number.

${ }^{\mathrm{y}} \mathrm{L}=$ linear, $\mathrm{Q}=$ quadratic.

ns, *, ** Nonsignificant or significant at $P \leq 0.05$ or 0.01 , respectively.

\section{Literature Cited}

Bleasdale, J.K.A. 1966. The effects of plant spacing on the yield of bulb onions (Allium cepa L.) grown from seed. J. Hort. Sci. 41:145-153.

Brewster, J. L. and P.J. Salter. 1980. The effect of plant spacing on the yield and bolting of two cultivars of overwintering bulb onions. J. Hort. Sci. 55:97-102.

Frappell, B.D. 1973. Plant spacing of onions. J. Hort. Sci. 48:19-28.

Hayslip N.C., D.D. Gull, V.L. Guzman, J.R. Shumaker, and R.M. Sonoda. 1987. Bulb onion production in Florida. Florida Coop. Ext. Ser., Inst. Food \& Agr. Sci., Univ. of Florida. 6-5M87.

Kelbert, D.G.A. and D.S. Burgis. 1962. Adaptable varieties, herbicides, and plant spacing for bulb onions on sandy land. Proc. Fla. State Hort. Soc. 75:153-156.

McGeary, D.J. 1985. The effects of plant density on shape, size, uniformity, soluble solid content, and yields of onions suitable for pickling. J. Hort. Sci. 60:83-87.

SAS Institute. 1989. SAS/STAT user's guide, version 6, 4th ed. SAS Inst., Cary, N.C.

U.S. Department of Agriculture. 1985. United States standard for grades of Bermuda-Granex-Grano type onions. U.S. Dept. Agr., Agr. Marketing Serv., Washington, D.C. 